BECHTEL BETTIS, INC.

WEST MIFFLIN, PENNSYLVANIA

MATERIALS TECHNOLOGY

INFORMATION BRIEF

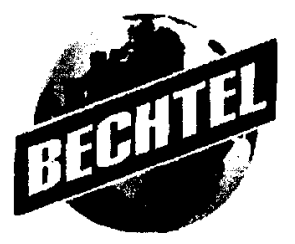

Title:

Author:

Date:

Summary:

Introduction:
Carbon-Carbon Composites as Recuperator Materials for Direct Gas Brayton Systems.

Richard A. Wolf

\section{JUL 192006}

Of the numerous energy conversion options available for a space nuclear power plant (SNPP), one that shows promise in attaining reliable operation and high efficiency is the direct gas Brayton (GB) system. In order to increase efficiency, the GB system incorporates a recuperator that accounts for nearly half the weight of the energy conversion system (ECS). Therefore, development of a recuperator that is lighter and provides better performance than current heat exchangers could prove to be advantageous. The feasibility of a carbon-carbon $(\mathrm{C} / \mathrm{C})$ composite recuperator core has been assessed and a mass savings of $60 \%$ and volume penalty of $20 \%$ were projected. ${ }^{1}$ The excellent thermal properties, high-temperature capabilities, and low density of carbon-carbon materials make them attractive in the GB system, but development issues such as material compatibility with other structural materials in the system, such as refractory metals and superalloys, permeability, corrosion, joining, and fabrication must be addressed.

The energy conversion concept chosen by the NRPCT for Project Prometheus was a direct gas Brayton (GB) system utilizing a He-Xe coolant/working fluid. The closed Brayton cycle energy conversion system (ECS) for space applications has been studied extensively by NASA since the 1960 s. The aerospace and commercial power industries commonly use Brayton systems, and there is a substantial amount of design and operational experience. ${ }^{2}$

One of the critical components in the GB system is the recuperator, which is responsible for significant enhancement of the overall system efficiency and is typically the heaviest component in the Brayton ECS. ${ }^{1}$ The recuperator reduces entropy generation and increases cycle efficiency by transferring thermal energy between the hot and cold portions of the working fluid. In general, higher turbine inlet temperatures and colder compressor inlet temperatures improve system efficiency, becoming the key design drivers for the reactor and radiator temperatures, respectively (Figure 1).

Conventional recuperators are thin-sheet metallic heat exchangers made of 300-series stainless steels or high-temperature nickel-based superalloys such as Hastelloy $X$. Prometheus' demanding performance targets for efficiency and weight reduction may exceed the limits of conventional ECS materials. As a result, development and design of the recuperator should be addressed. Some options include altering cycle state points (Figure 2 ) $^{3}$ to reduce performance expectations or incorporating advanced materials to reduce mass while improving heat transfer. ${ }^{4}$ 
Background:

Present $\mathrm{C} / \mathrm{C}$

Conceptual Development
A promising advanced material candidate is a carbon-carbon (C/C) composite. $\mathrm{C} / \mathrm{C}$ is used in many engineering, especially aerospace, applications due to its high thermal conductivity, high-temperature capability, exceptional stiffness, low density and high strength-to-density ratio. ${ }^{5}$ Carbon-carbon materials can withstand operating temperatures up to $2273 \mathrm{~K}\left(2000^{\circ} \mathrm{C}\right)$; however, at this temperature they require a non-oxidizing environment or protective coatings. $\mathrm{C} / \mathrm{C}$ composites have demonstrated room temperature thermal conductivities in excess of $250 \mathrm{~W} / \mathrm{mK}$ (parallel to fiber direction), which is over 10 times that of current heat exchanger materials. ${ }^{6}$ Finally, the thermal and mechanical properties of carbon-carbon composites can be tailored by fiber selection, fiber orientation, and/or processing conditions.

Developments in $\mathrm{C} / \mathrm{C}$ heat exchangers were conducted under the Air Force Research Laboratory Thermal Component Development Program, which began in 1996. Stevenson and Vrable ${ }^{6}$ studied the development of a carbon-carbon composite heat exchanger $(\mathrm{HX})$ for aircraft applications. The type of heat exchanger selected was a plate-fin, cross-flow design resulting in a $40 \%$ reduction in weight compared to conventional alloys. Although metal core heat exchangers used offset strip-fin designs, manufacturing capabilities limited $\mathrm{C} / \mathrm{C}$ to the plain plate-fin design.

Kearns, Anderson, and Watts ${ }^{7}$ examined brazing carbon-carbon plates and fins to form the heat exchanger core. The braze material consisted of $70 \%$ nickel, $18 \%$ silicon, and $12 \%$ chromium with an alloy melting point of $1473 \mathrm{~K}\left(1200^{\circ} \mathrm{C}\right)$. SEM analysis showed that the silicon and chromium reacted to form carbides, while the nickel remained in the bulk of the braze material. The study concluded that fin heights varied enough to prevent uniform contact between the corrugations and parting sheets. This reduced the amount of area available for bonding and produced structures with very little strength. It was concluded that instead of brazing fins to the plate, a preferred alternative was to manufacture an integral design that co-processes the fins and plates as one piece.

Barrett ${ }^{1}$ assessed closed Brayton cycle $(C B C)$ recuperators for space power applications. Barrett defined a series of CBC state point cases and conceptually designed several recuperators using temperature, pressure, and fluid flow information. Results showed that mass and pressure-loss goals were difficult to achieve using conventional $\mathrm{HX}$ technology. Traditional recuperator designs exceeded the mass target by $15 \%$ with a total pressure-loss of $33 \%$. Barrett suggested options to reduce system development risk by modifying cycle state points, using enhanced heat transfer techniques, or incorporating advanced materials such as carbon-carbon composites.

Barrett ${ }^{4}$ conducted conceptual development of the $\mathrm{C} / \mathrm{C}$ recuperator core at NASA Glenn Research Center. Studies compared the mass and volume characteristics of eight $\mathrm{HX}$ designs, including six metal designs with different plate-fin geometries and two $\mathrm{C} / \mathrm{C}$ designs with the same plate-fin geometry, but different fiber-based materials. The recuperator designs were generated using a NASA design code HXCALC, which uses thermal requirements, state point information, and fluid properties to roughly size the heat exchanger.

Calculations proceed in an iterative loop, adjusting geometries, until thermal load and pressure-drop requirements are satisfied. Then, the final geometry is used to estimate the recuperator's mass. 


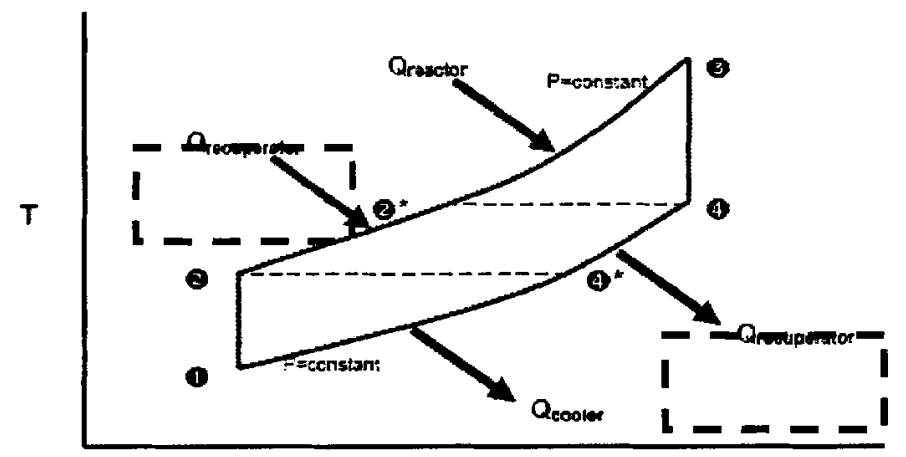

s

Figure 1: Temperature - Entropy Diagram²

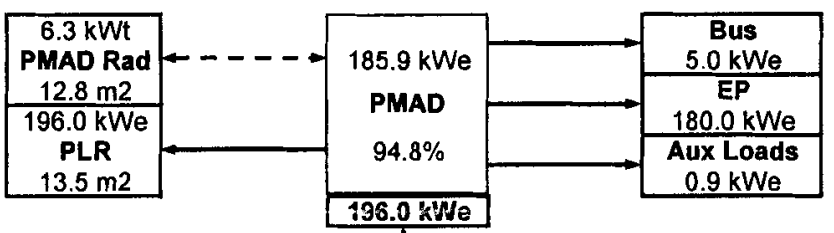

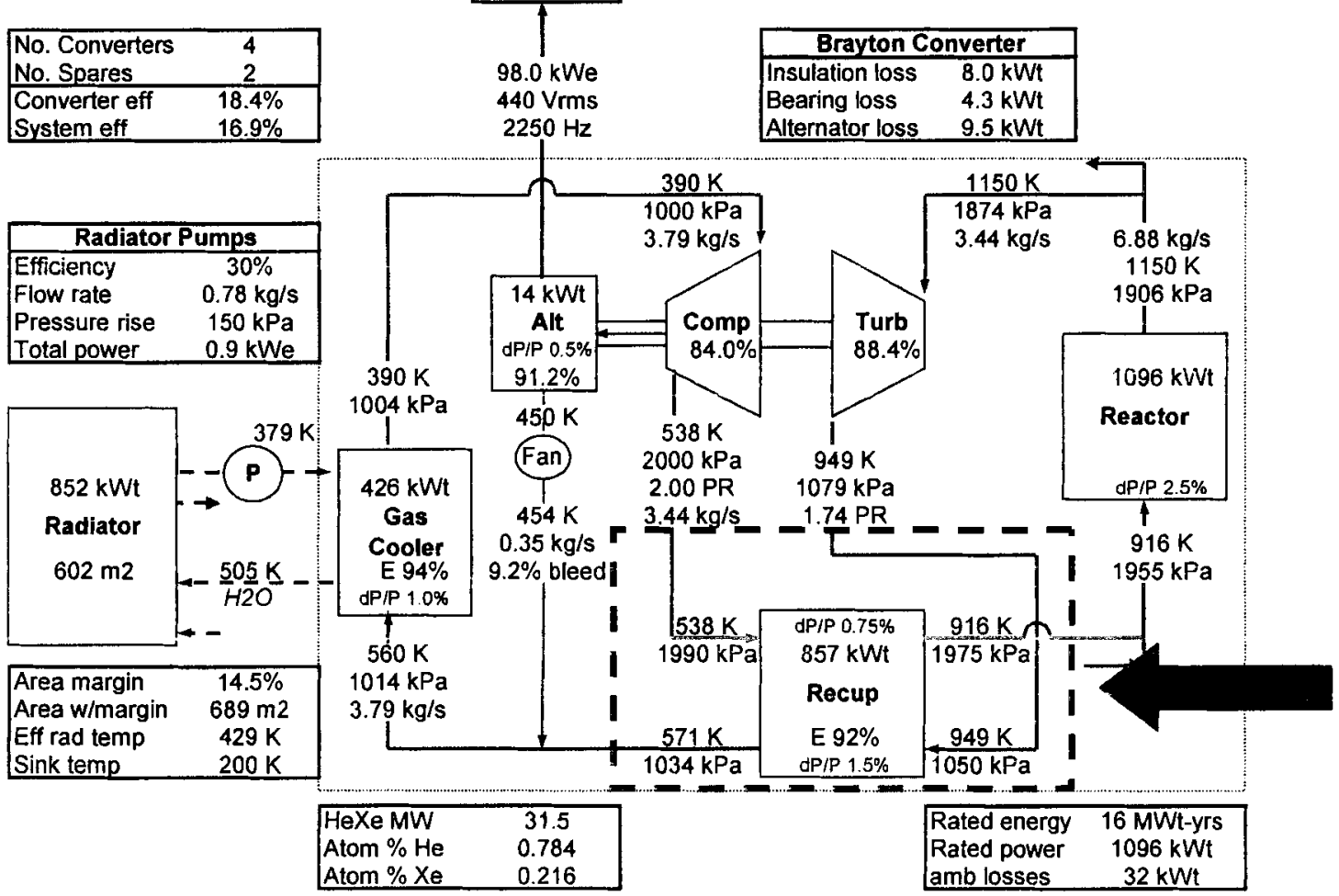

Figure 2: Direct Gas Brayton Cycle State Point Diagram ${ }^{3}$ 
Barrett predicted $\mathrm{C} / \mathrm{C}$ recuperator cores to have lower masses than metallic heat exchangers in all cases, although most $\mathrm{C} / \mathrm{C}$ designs showed an increase in volume compared to the metallic heat exchangers. The increase in volume is due to the choice of $\mathrm{C} / \mathrm{C}$ plain-fin geometry (Figure 3 ), which is limited by manufacturing capabilities. The $\mathrm{C} / \mathrm{C}$ plain-fin geometry requires more surface area than the offset strip-fin design due to a lower average convective heat transfer coefficient. At lower thermal loads, the $\mathrm{C} / \mathrm{C}$ mass advantage diminishes; therefore, $\mathrm{C} / \mathrm{C}$ plain-fin recuperators are only advantageous at thermal loads of $300 \mathrm{kWt}$ or greater, providing a $60 \%$ mass savings and $20 \%$ volume penalty.

Development Concerns:
NASA is continuing development of a C/C recuperator under a SBIR contract ${ }^{B}$ with Allcomp, Inc. Detailed information regarding the physical characteristics, mechanical and thermal properties of the $\mathrm{C} / \mathrm{C}$ recuperator core should be contained in Allcomp's final report.

The Prometheus gas Brayton system was designed to operate for 15 to 20 years. In order to accomplish this goal some potentially mission-threatening issues were considered, including gas leakage of the working fluid and mass transport of contaminants to other plant or core components. The NRPCT Design Team has introduced several areas of concern for recuperator development ${ }^{9}$ :

1. Impact on mechanical properties during operation

2. Design requirements (permeability and heat transfer properties)

3. Fabrication challenges

4. Material availability assessment

5. Joining issues

6. Compatibility issues in the primary working fluid

\section{Mechanical Properties of Carbon-Carbon Composites}

The structural properties of carbon-carbon composites are generally controlled by the orientation, volume fraction, and properties of the fibers. Additionally, process-induced stresses, heat treatments, and fiber-matrix interactions also affect the primary properties. ${ }^{5}$ In general, mechanical properties can be tailored by selecting the correct modulus fibers and arranging the fibers in the direction of the applied load (Table 1). 
The characteristics of the interfacial bonding between the matrix and fiber typically govern the mechanical properties of the $\mathrm{C} / \mathrm{C}$ composite. ${ }^{5}$ When the bonding between the fibers and matrix is strong, cracks that form in the matrix will propagate across the fiber-matrix interface resulting in brittle fracture. Conversely, weak interfaces between the fibers and matrix allow matrix cracking to occur without crack propagation through the fibers. Intact fibers bridge the matrix cracks and maintain a load-bearing capability until the load initiates fiber fracture. This type of failure exhibits pseudo-plastic behavior due to matrix cracking and fiber movement.

Fiber treatments and processing methods are often varied to optimize mechanical properties and to tailor the interfacial characteristics of the $\mathrm{C} / \mathrm{C}$ composite. Two processes have been developed to produce highperformance carbon-carbon composites: liquid impregnation and chemical vapor infiltration $(\mathrm{CVI}) .^{10}$ The liquid impregnation method commonly uses thermosetting or thermoplastic polymers as the matrix precursor to form a prepreg. The prepreg is a ready-to-mold component, usually in laminate form, consisting of a matrix (organic resin) and fiber reinforcement. In order to achieve the high-temperature properties of a carbon material, the prepreg matrix must be transformed into a carbon residue (pyrolysis). Pyrolysis strongly influences the strength of the fiber-matrix interface due to densification and shrinkage of the matrix. To achieve a higher density and stronger matrix, the $\mathrm{C} / \mathrm{C}$ composite is cycled through several impregnation/pyrolysis processes. Graphitization treatment of the carbon matrix may be included to encourage densification and opening of porosity to aid reimpregnation cycles.

The CVI of carbon uses gaseous hydrocarbons such as methane to deposit a carbon matrix on the external and internal surfaces of a porous carbon fiber preform. ${ }^{5}$ Three types of carbon microstructure are commonly seen in CVI fabrication: smooth laminar, rough laminar, and isotropic. The microstructure is controlled by processing parameters: temperature, pressure, gas composition, and flow rate. An isotropic CVI matrix exhibits lower mechanical properties due to lower density and closed porosity. The smooth laminar matrix has a strong fiber-matrix interface and produces composites with high strength and stiffness but brittle fracture behavior. A rough laminar matrix exhibits pseudo-plastic fracture behavior due to a loosely bonded fiber-matrix interface. The major drawback of $\mathrm{CVI}$ is the very slow rate of deposition leading to high final cost. Therefore, using impregnation to produce relatively uniform open pores, followed by CVI for densification is an attractive option.

$\mathrm{C} / \mathrm{C}$ composites are unique in that their mechanical properties do not typically degrade with increasing temperature until $2273 \mathrm{~K}\left(2000^{\circ} \mathrm{C}\right) .^{10}$ The properties of the matrix and fiber-matrix interface often dictate the effect of temperature on the shear, cross-fiber tensile, and compressive strengths of the composites. Generally, these properties improve with increasing temperature, which is attributed to the annealing of matrix microcracks. Creep behavior has received little attention to date, but is predicted to be at least four orders of magnitude lower than that of most ceramics. $^{10}$ 
Polyacrylonitrile (PAN)-based fibers woven in three-directions have been shown to posses very high-strength. Increasing density through a number of impregnation/CVI cycles will also help to improve the mechanical properties of the composite. Current development of the $\mathrm{C} / \mathrm{C}$ recuperator under Allcomp ${ }^{8}$ should give detailed information on the $\mathrm{C} / \mathrm{C}$ mechanical properties. Information on the type of carbon-fiber, fiber lay-up, matrix precursor, and processing conditions should also be available.

\begin{tabular}{|c|c|c|c|c|c|c|c|c|c|c|}
\hline \multicolumn{11}{|c|}{ Table 1: Typical Mechanical Properties of C/C Composites at Room Temperature ${ }^{\mathrm{a}}$} \\
\hline \multirow{3}{*}{$\begin{array}{c}\text { Mechanical } \\
\text { property }\end{array}$} & \multirow{3}{*}{ Hitco $^{b}$} & \multirow{2}{*}{\multicolumn{3}{|c|}{$\mathrm{ASM}^{c}$}} & \multicolumn{6}{|c|}{ Carbon $^{\text {d }}$} \\
\hline & & & & & \multicolumn{3}{|c|}{$2 \mathrm{D}$} & \multicolumn{3}{|c|}{ 3D } \\
\hline & & UD & $2 \mathrm{D}$ & $3 D$ & CP-M & $\mathrm{CP}-\mathrm{T}$ & wo & ROD-L & ROD-H & wo \\
\hline $\begin{array}{l}\text { Tensile Strength } \\
\text { (MPa) }\end{array}$ & 276 & $\begin{array}{l}1000(x) \\
2.0(z)\end{array}$ & $\begin{array}{c}350(x-y) \\
5.0(z)\end{array}$ & $\begin{array}{l}170(x-y) \\
300(z)\end{array}$ & 180.3 & 129.2 & 161.1 & 161 & 151 & 225 \\
\hline $\begin{array}{l}\text { Tensile Modulus } \\
\text { (GPa) }\end{array}$ & 90 & $\begin{array}{l}260(x) \\
3.4(z)\end{array}$ & $\begin{array}{c}115(x-y) \\
4.1(z)\end{array}$ & $\begin{array}{l}55(x-y) \\
96(z)\end{array}$ & 90.2 & 57.2 & 66.9 & 116 & 116 & 85 \\
\hline $\begin{array}{l}\text { Compression } \\
\text { Strength } \\
\text { (MPa) }\end{array}$ & 207 & $\begin{array}{l}620(x) \\
-(z)\end{array}$ & $\begin{array}{l}150(x-y) \\
--(z)\end{array}$ & $\frac{-(x-y)}{140(z)}$ & - & - & - & - & - &.- \\
\hline $\begin{array}{l}\text { Compression } \\
\text { Modulus } \\
\text { (GPa) }\end{array}$ & - & $\begin{array}{l}250(x) \\
\cdots(z)\end{array}$ & $\begin{array}{l}100(x-y) \\
-(z)\end{array}$ & $\begin{array}{l}--(x-y) \\
90(z)\end{array}$ & - & - & - & - & - & - \\
\hline $\begin{array}{l}\text { Shear Strength } \\
\text { (MPa) }\end{array}$ & & & & - & 31.9 & 43.9 & 31.4 & 17.6 & 18.4 & 17.1 \\
\hline $\begin{array}{l}\text { Shear Modulus } \\
\text { (GPa) }\end{array}$ & & & & & 5.4 & 5.4 & 5.4 & 0.56 & 0.89 & 1.5 \\
\hline \multicolumn{11}{|c|}{ 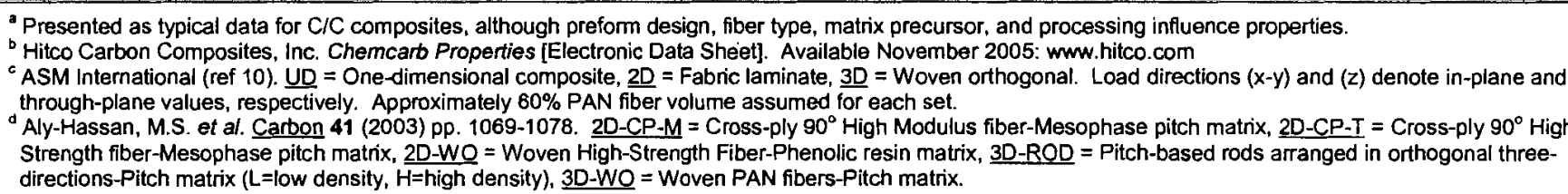 } \\
\hline
\end{tabular}

2. Impact of Design Requirements on $\mathrm{C} / \mathrm{C}$ Recommendation

A critical flaw of the direct gas Brayton system is that it is susceptible to a single point failure in which the working fluid will leak out of the system. ${ }^{2}$ For this reason, gas leakage due to failure of a recuperator material is a mission-threatening concern. Because most composite materials are porous, the current design of a $\mathrm{C} / \mathrm{C}$ recuperator core should incorporate metallic side- and end-walls used for pressure-vessel containment of the working fluid. The design must comply with the ASME boiler and pressure vessel codes. Considerations for the pressure vessel should be focused on the load-sharing and strain compatibility of the metal and composite under pressure cycling, thermal-strain compatibility of the metal and composite under thermal cycling, and stress-rupture and creep capability of the composite under long-term pressurized loads. ${ }^{11}$

There is also a concern over inter-passage gas leakage between $\mathrm{C} / \mathrm{C}$ plates, which will reduce overall efficiency. One method of prevention is 
to densify the $\mathrm{C} / \mathrm{C}$ composite with multiple impregnation/pyrolysis/CVI cycles. The high-density composite will also provide better thermal conductivity. Another idea that is under consideration is to insert thin metallic foils between $\mathrm{C} / \mathrm{C}$ sections while still improving the overall performance from an all metallic core. ${ }^{1}$ Improved assembly methods and brazing techniques are necessary to develop this technology.

Thermal conductivity and density values for $\mathrm{C} / \mathrm{C}$ composites are important recuperator design considerations, although wide variations in the data exist for carbon-carbon materials (Table 2). Carbon-carbon composites present the opportunity to tailor thermo-physical properties, which can be controlled by the different fiber, matrix, or processing options available. ${ }^{5}$ For instance, in-plane conductivity is greater than through-plane conductivity; therefore, fiber orientation could be tailored to increase thermal performance in a specific direction. Carbon-carbon processing methods can affect conductivity values such that a more graphitic matrix exhibits higher conductivities than an isotropic matrix. Typically, a pitchbased fiber or matrix will exhibit a graphitic microstructure and have higher thermal conductivity values than a phenolic-resin.

\begin{tabular}{|c|c|c|c|c|c|c|}
\hline \multicolumn{7}{|c|}{ Table 2: Typical Thermal Properties of C/C Composites ${ }^{a}$} \\
\hline \multirow{2}{*}{$\begin{array}{l}\text { Thermal } \\
\text { property }\end{array}$} & \multirow{2}{*}{ Hitco $^{b}$} & \multicolumn{3}{|c|}{$\mathbf{A S M}^{\mathrm{c}}$} & \multicolumn{2}{|c|}{ Toyo $^{d}$} \\
\hline & & UD & 20 & $3 D$ & $2 D$ & Felt \\
\hline CTE $\left(10^{-8} / \mathrm{K}\right)$ & 1.4 & $\begin{array}{c}1.1(x) \\
10.1(z)\end{array}$ & $\begin{array}{l}1.3(x-y) \\
6.1(z)\end{array}$ & $\begin{array}{c}1.3(x-y) \\
1.3(z)\end{array}$ & $\begin{array}{l}<1(x-y) \\
7.7(z)\end{array}$ & $\begin{array}{l}1.7(x) \\
2.3(y) \\
5.3(z)\end{array}$ \\
\hline $\begin{array}{l}\text { Thermal } \\
\text { Conductivity } \\
\text { (W/m-K) }\end{array}$ & 34 & $\begin{array}{c}125(x) \\
10(z)\end{array}$ & $\begin{array}{c}95(x-y) \\
4(z)\end{array}$ & $\begin{array}{c}57(x-y) \\
80(z)\end{array}$ & $\begin{array}{c}35(x-y) \\
5(z)\end{array}$ & $\begin{array}{l}390(x) \\
320(y) \\
190(z)\end{array}$ \\
\hline \multicolumn{7}{|c|}{$\begin{array}{l}\text { Presented as typical data for } \mathrm{C} / \mathrm{C} \text { composites, although pre-form design, fiber type, matrix precursor, and processing } \\
\text { influence properties. } \\
\text { - Hitco Carbon Composites, Inc. Chemcarb Properties [Online Data Sheet]. Available November 2005: ww.hitco.com } \\
\text { "ASM International (ref } 10), \underline{\mathrm{UD}}=\text { One-dimensional composite, } \underline{2 \mathrm{D}}=\mathrm{Fabric} \text { laminate, } 3 \mathrm{D}=\text { Woven orthogonal. Load } \\
\text { directions }(x-y) \text { and }(z) \text { denote in-plane and through-plane values, respectively. Approximately } 60 \% \text { PAN fiber volume } \\
\text { assumed for each set. } \\
\text { - Toyo Tanso, Co. Characteristics of } \mathrm{C} / \mathrm{C} \text { composite [Online Data Sheet]. Available November } 2005 \text { : www.toyotanso.co.jp }\end{array}$} \\
\hline
\end{tabular}

\section{Fabrication Challenges}

The major heat exchanger components of a plate-fin, cross-flow core include corrugated fins, parting sheets, and channel edge closures ${ }^{6}$ (Figure 4). As mentioned, the use of $\mathrm{C} / \mathrm{C}$ composites allows each component to be tailored for thermal and structural performance through materiais and processing seiection. Although this option exists, it is often labor intensive or processing becomes a cost limiting factor. For these reasons, a plain plate-fin design has been envisioned for the $\mathrm{C} / \mathrm{C}$ recuperator core.

The corrugated plate-fins require both thermal and structural design considerations. High in-plane thermal conductivity is most important, therefore fiber orientation in the direction of conductivity must be considered for optimization. High-thermal conductivity fibers and a dense 
graphitic matrix will also aid thermal performance. The increase in performance by fiber selection and orientation could ease the concern over plain-fin geometry and help reduce the projected volume penalty. Also, since heat transfer surface area within the core dominates performance, the fin packing density must be enhanced. Reducing the plate-fin thickness to increase packing density is required but is limited by fabricability concerns.

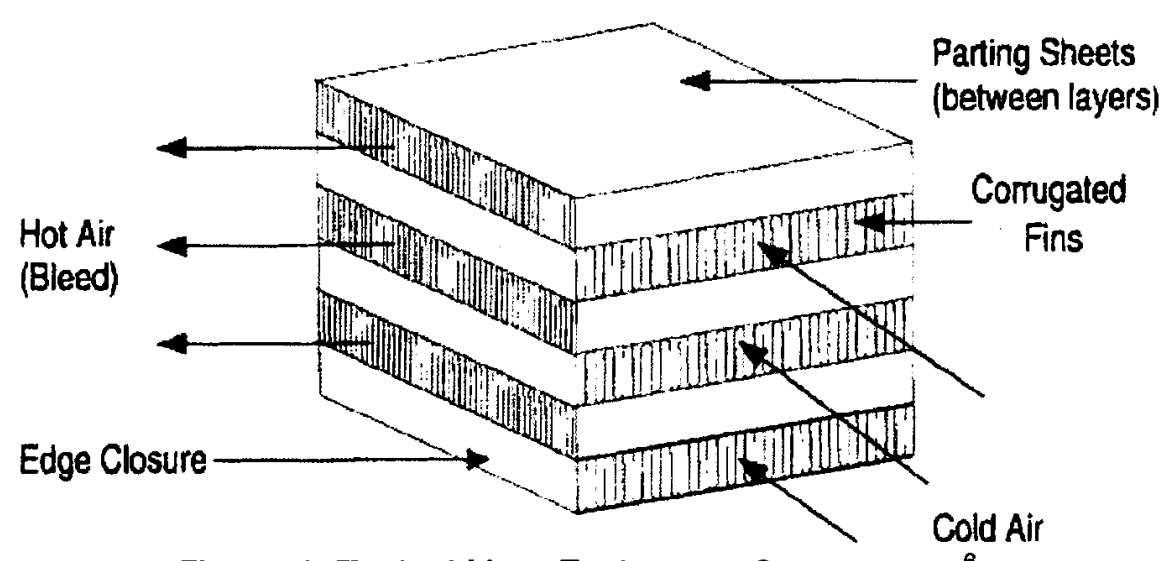

Figure 4: Typical Heat Exchanger Components ${ }^{6}$

The parting sheets serve primarily a structural function and are the principal leakage boundary between the hot and cold airflow streams. For the parting sheets, through-plane conductivity is important and sheets should be as thin as possible while meeting thermal, structural, and permeability requirements. Since $\mathrm{C} / \mathrm{C}$ composites are inherently porous, additional processing steps must be utilized to increase the composite density. The use of thin metallic foils between the parting sheets may help to prevent leakage, but incorporates more challenges to the fabrication concern. The metallic foils must have a low coefficient of thermal expansion (CTE) and high-temperature capabilities, and must meet compatibility requirements with the composite and gas Brayton system.

Channel edge closures serve a structural function by acting as load carrying members and leakage boundaries. For the conceptual recuperator design, the side- and end-walls are expected to be metallic to meet the critical permeability requirements. The composite core and metallic pressure boundary must be compatible and conform to the ASME boiler and pressure-vessel code.

Fabrication of a $\mathrm{C} / \mathrm{C}$ heat exchanger core has been demonstrated for aircraft applications. ${ }^{6,7}$ Conventional core design (Figure 5) mimics the procedure used to produce metallic heat exchangers by brazing each corrugated layer to the flat parting sheet on both the top and bottom to form a layer. Each layer is brazed together to form the core. The study showed that fin heights varied up to $6 \%$, with only the high points attaching to the parting sheet, thus reducing structural performance. The study concluded that control over composite fabrication is essential and must be further developed. 
An innovative approach to minimize fabrication and cost, while maintaining thermal and structural performance has also been evaluated. ${ }^{6,7}$ This "integral plate-fin" design (Figure 5) took advantage of the unique fabrication possibilities of $\mathrm{C} / \mathrm{C}$ composite materials. Instead of processing each layer of the $\mathrm{HX}$ core individually and brazing them together, the integral design allows each layer to be constructed and cocured as an integral unit. The size of the Prometheus recuperator may prevent the use of this technology.
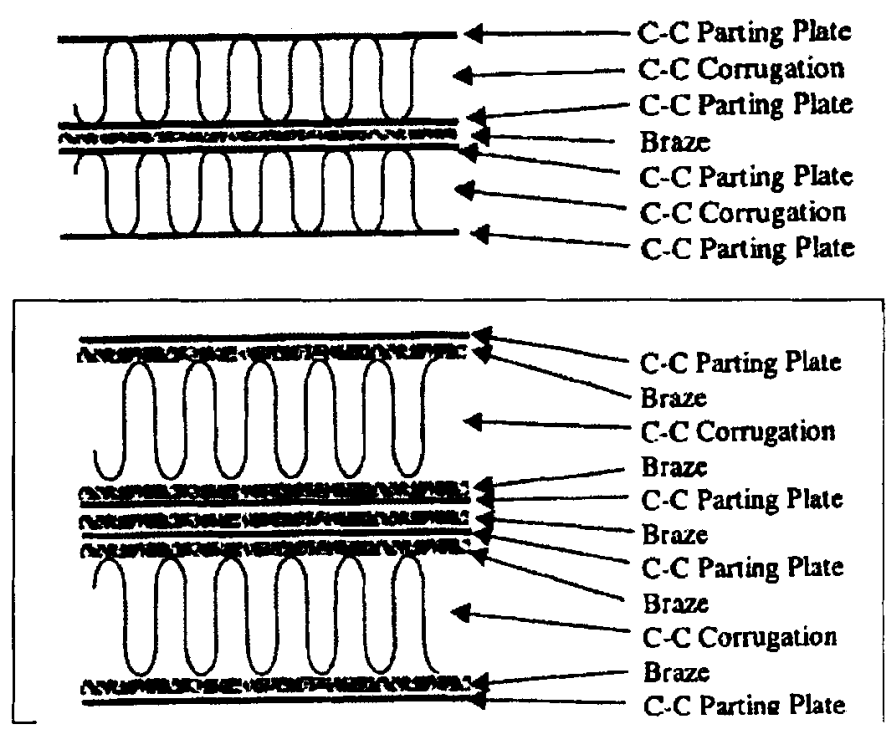

Figure 5: Integral (top) and Conventional (bottom) Plate-Fin Design ${ }^{7}$

The study ${ }^{6}$ also demonstrated $\mathrm{C} / \mathrm{C}$ material optimization in the $\mathrm{HX}$ design. Commercial materials and existing processes were used to reduce time and cost. Three standard processing methods were evaluated to give favorable properties. The high thermal conductivity process used more costly steps to produce a graphitic composite from a pitch-matrix prepreg. The structural process was less expensive and optimized mechanical properties by pyrolyzing a phenolic-matrix prepreg without graphitization. Finally, the mixed method pyrolized and graphitized a phenolic-resin prepreg to provide intermediate strength and thermal properties.

It is expected that current $\mathrm{C} / \mathrm{C}$ recuperator fabrication development by Alicomp will take these problems into consideration. Innovative approaches to reduce cost and ease of fabrication may be utilized while maintaining quality. Details regarding fabrication should be included in Allcomp's final report. ${ }^{8}$

\section{Material Availability}

Carbon-carbon composite materials are readily available and are primarily used in the aerospace and defense industries for aircraft brakes, rocket nozzles, and heat shieids. ${ }^{5}$ The use of $\mathrm{C} / \mathrm{C}$ materials has been limited by 
its poor oxidation resistance at high temperatures. Aircraft braking materials capture the majority of the market and are the cheapest components available, whereas high-density, three-dimensional composites are more expensive.

The price of carbon-carbon varies considerably depending on the end-use and method of production. Carbon-carbon raw material costs vary according to the type and geometries of the fibers and matrix precursor. Epoxy resins are less expensive than other high-carbon-yield polymers. Chopped, low-strength fibers are less expensive than continuous highmodulus fibers, and the cost of weaving varies according to the weave geometry, number of dimensions, and type of fiber. ${ }^{12}$

5. Joining lssues

Integrating a carbon-carbon composite into an otherwise all-metallic energy conversion system raises joining concerns. The CTE mismatch at $\mathrm{C} / \mathrm{C}$ to metal interfaces may create excessive thermal stresses causing failure at the joint and catastrophic gas leakage. The joining technology between $\mathrm{C} / \mathrm{C}$ and metal is underdeveloped and unproven for hightemperature joint reliability over a long mission lifetime.

In order to join a $\mathrm{C} / \mathrm{C}$ recuperator to metallic headers, Kennel and Deutchman ${ }^{13}$ described a technique that used an ion beam to deposit a metallic interface material at shallow depths into the surface of each material to be bonded. With the surfaces treated, they could be joined together using a metal-to-metal bonding technique. Materials Resources International' ${ }^{14}$ advertised a braze method to join $\mathrm{C} / \mathrm{C}$ with metal and withstand temperatures up to $2273 \mathrm{~K}\left(2000^{\circ} \mathrm{C}\right)$. The method uses liquid infiltration and liquid phase sintering of a powder based perform to produce wide gap joints able to accommodate expansion mismatch. These joining technologies are unproven in long-term, high-temperature service, and further research must be conducted.

\subsection{Compatibility Concerns}

In addition to potential gas leakage, the degradation of plant or core materials due to mass transport of impurities via the gas stream is a serious concern. In the direct gas Brayton system, materials from the reactor core and ECS are coupled thermodynamically by circulating $\mathrm{He}$ Xe gas, which serves as the core coolant and working fluid in a single, high-temperature, gas circuit. Although core and plant materials are compatible with inert He-Xe gas, there may be significant compatibility issues with impurities entering the circulating gas, specifically oxygen, nitrogen, and carbon. These impurities are of particular concern since they are reactive with, and may be detrimental to, plant and core materials at elevated temperatures. Degradation mechanisms include interstitial embrittlement of refractory metals, deposition of surface carbides, decarburization of superalloys, and diffusion of interstitials into the material matrix; all of which could be detrimental to important materials properties such as creep, fracture toughness, and fatigue..$^{15}$ 
Incorporating a carbon-carbon composite into the working fluid gas circuit would add to the compatibility concern. Although $\mathrm{C} / \mathrm{C}$ composites are chemically compatible and corrosion resistant with $\mathrm{He}-\mathrm{Xe}$ gas, they are sensitive to exposure to corrosive impurities in the gas stream. Logically, carbon-carbon composites must be considered a potential source of active interstitial contaminants. In the case where an oxygen potential is required for superalloy maintenance, carbon-carbon may produce $\mathrm{CO}$ by corrosion reactions. On the other hand, when a very low oxygen potential environment is necessary for refractory metal maintenance, there is still a concern over surface transport of free carbon "dust" into the working fluid. Both situations could yield concentrations of $\mathrm{C}$ or $\mathrm{CO}$ that are unacceptable to the contamination sensitivity of refractory metals, or potentially drive the coolant chemistry into a regime where superalloys carburize or decarburize.

\subsection{Corrosion Effects of Carbon-Carbon}

One of the key concerns with carbon or graphite is its reactivity with oxidizing species, especially at high-temperatures. High-temperature gascooled reactor (HTGR) literature ${ }^{16}$ suggests that the typical gas composition in a helium gas-cooled reactor will consist of impurities $\mathrm{H}_{2}$, $\mathrm{H}_{2} \mathrm{O}, \mathrm{CO}, \mathrm{CH}_{4}, \mathrm{~N}_{2}$, and $\mathrm{O}_{2}$ (Table 3). The main oxidizing species are $\mathrm{O}_{2}$ and $\mathrm{H}_{2} \mathrm{O}$, although the amount of $\mathrm{O}_{2}$ present in the gas coolant may be negligible. Even if great care was taken to prevent oxygen potential in the gas, $\mathrm{H}_{2} \mathrm{O}$ is difficult to remove from the system completely. Therefore, it is likely that the corrosion reaction of carbon-carbon in a gas-cooled reactor will take the form:

$$
\mathrm{C}_{(\mathrm{s})}+\mathrm{H}_{2} \mathrm{O}_{(\mathrm{g})} \rightarrow \mathrm{CO}_{(\mathrm{g})}+\mathrm{H}_{2(\mathrm{~g})}
$$

\begin{tabular}{|c|c|}
\hline \multicolumn{2}{|c|}{$\begin{array}{c}\text { Table 3: Approximate Impurity Levels in HTGR } \\
\text { Helium Coolant }\end{array}$} \\
\hline Impurity & Partial Pressure (Pa) $^{\text {Ib }}$ \\
\hline $\mathrm{H}_{2}$ & 50 \\
\hline $\mathrm{H}_{2} \mathrm{O}$ & 0.05 \\
\hline $\mathrm{CO}$ & 5 \\
\hline $\mathrm{CH}_{4}$ & 5 \\
\hline $\mathrm{CO}_{2}$ & $<0.1$ \\
\hline $\mathrm{N}_{2}$ & 0.5 \\
\hline $\mathrm{O}_{2}$ & $<<0.1$ \\
\hline
\end{tabular}

The primary consequences of the suggested reaction are that solid carbon is gasified and the reaction products can alter coolant chemistry. As the solid carbon is lost, the interfacial bond between the fiber and 
matrix becomes debonded and a significant reduction in mechanical and thermal properties of the composite becomes unavoidable. ${ }^{5}$

Considering coolant chemistry, HTGR studies $17,18,19,20,21$ have concluded that corrosion of high-temperature superalloys is related to the presence of low partial pressures of $\mathrm{H}_{2} \mathrm{O}, \mathrm{CO}$, and $\mathrm{CH}_{4}$ in the He gas. Depending on the gas composition and temperature, superalloys can carburize, decarburize, or oxidize (Figure 6). This will depend primarily on the $\mathrm{CO}$ and $\mathrm{H}_{2} \mathrm{O}$ concentrations, both of which are affected by the carbon-water gas equilibrium reaction. Variations in $\mathrm{CO}$ concentration will have a major effect on gas/metal interactions and can represent a critical partial pressure at which oxides and carbides coexist in the superalloy. Below this critical $\mathrm{CO}$ level, excess $\mathrm{H}_{2} \mathrm{O}$ concentration (low $\mathrm{CH}_{4}$ ) may cause the formation of surface oxides and total decarburization; whereas, low $\mathrm{H}_{2} \mathrm{O}$ concentration (high $\mathrm{CH}_{4}$ ) may cause surface carbides and continuous carburization. ${ }^{16,20}$

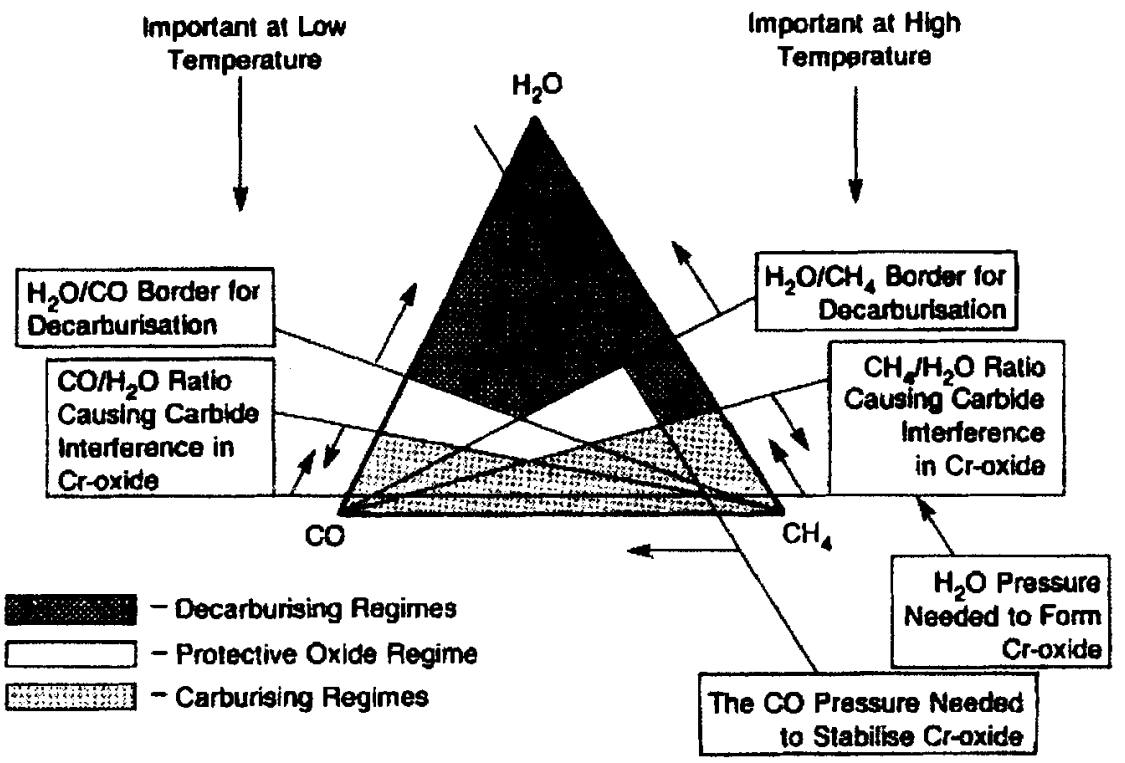

Figure 6: Diagram of carburization, decarburization, and oxidation regimes for a superalloy with $\mathrm{Cr}$-oxide protection ${ }^{21}$

Refractory metal alloys retain useful strength and properties at hightemperatures, although there are significant concerns regarding interstitial embrittlement in the presence of $\mathrm{C}, \mathrm{O}, \mathrm{N}$, and $\mathrm{H}$. One of the most significant differences between the refractory metals of group $\mathrm{Vb}(\mathrm{Nb}$ and $\mathrm{Ta}$ ) and group $\mathrm{VIb}$ (Mo and $\mathrm{W}$ ) is the solubilities of interstitial elements. ${ }^{22}$ Molybdenum and tungsten have considerably lower interstitial solubility than the group $\mathrm{Vb}$ refractory metals (Table 4). At higher impurity levels, refractory metals can be expected to form carbides, oxides, and nitrides. Therefore, the change in coolant chemistry due to carbon gasification or the release of free carbon "dust" is of great concern. 


\begin{tabular}{|c|c|c|c|c|}
\hline \multicolumn{5}{|c|}{ Table 4: Estimated Solubilities for Refractory Metals $\left(\mathbf{p p m}_{\mathrm{w}}\right)^{22}$} \\
\hline Interstitial & $\mathrm{Nb}$ & $\mathrm{Ta}$ & \multicolumn{1}{c|}{ Mo } & \multicolumn{1}{c|}{ W } \\
\hline $\mathrm{C}$ & 100 & 70 & $<1.0$ & $<0.1$ \\
\hline $\mathrm{O}$ & 1000 & 300 & 1.0 & 1.0 \\
\hline $\mathrm{N}$ & 300 & 1000 & 1.0 & $<0.1$ \\
\hline $\mathrm{H}$ & 9000 & 4000 & 0.1 & $\mathrm{~N} . \mathrm{D}$. \\
\hline $\begin{array}{c}\text { Carbide } \\
\text { Phases }\end{array}$ & $\begin{array}{l}\mathrm{NbC}_{1} \\
\mathrm{Nb}_{8} \mathrm{C}_{7}, \\
\mathrm{Nb}_{4} \mathrm{C}_{3}, \\
\mathrm{Nb}_{2} \mathrm{C}\end{array}$ & $\begin{array}{l}\mathrm{TaC}, \\
\mathrm{Ta}_{2} \mathrm{C}\end{array}$ & $\begin{array}{l}\mathrm{Mo}_{2} \mathrm{C}, \\
\mathrm{MoC}^{2}\end{array}$ & $\begin{array}{l}\text { WC } \\
\mathrm{W}_{2} \mathrm{C}\end{array}$ \\
\hline
\end{tabular}

\subsection{Corrosion Behavior of Carbon-Carbon}

Carbon-carbon corrosion is governed by structural defects or stress accumulation within the matrix as a result of carbonization shrinkage. ${ }^{5}$ The selection of matrix precursor, fiber, and processing conditions will therefore have an important effect. The reaction will commence at edge sites or porosity and proceed to regions of the laminar matrix, anisotropic matrix, isotropic matrix, fiber lateral surface, fiber ends, and finally, fiber cores. Graphitic carbon, with its denser, crystalline structure and lower proportion of reactive edge sites, does not begin to corrode until slightly higher temperatures. Gasification rate is increased by increasing operating temperature and reduced by increasing heat treatment temperature (HTT). The latter is believed to occur as a result of reducing reactive edge sites, retained impurities, and residual carbonization stresses.

The gasification of carbon-carbon typically begins at $623 \mathrm{~K}\left(350^{\circ} \mathrm{C}\right)$ and the corrosion rate is found to increase exponentially with temperature. ${ }^{5}$ Depending on the temperature regime, gasification attack can be uniform throughout the material or limited to the geometrical surface ${ }^{23}$ (Figure 6). At low temperatures $\left(<-773 \mathrm{~K}\left(500^{\circ} \mathrm{C}\right)\right)$, the rate-controlling steps of the reaction are chemical in nature and the reactions are so slow that corrosive gas can penetrate the carbon in depth. Corrosion occurs primarily at the high-energy reactive sites (edges and microcracks) causing rather uniform attack and thus reducing strength without changing the component geometry.

At high-temperatures $\left(>\sim 1173 \mathrm{~K}\left(900^{\circ} \mathrm{C}\right)\right)$, the rate-controlling step changes to diffusion controlled as gas diffuses through the boundary layer close to the solid carbon. In this regime, chemical reactivity is so high that all corrosive gas penetrating the boundary layer reacts immediately with the hot carbon surface. Therefore, the rate of gasification is controlled by the transport of gas to and from the reaction front. This type of corrosion will cause geometrical changes of the solid carbon. 
At temperatures between these two regimes ( $773-1173 \mathrm{~K}(500-$ $\left.900^{\circ} \mathrm{C}\right)$ ), the corrosion rate is controlled by in-pore diffusion, and the composite pore structure becomes a rate determining factor. The critical temperatures separating the regimes are not well defined or exactly determined, and the reactions are very difficult to model with any degree of confidence. The reaction rate is difficult to express due to changes in the reaction surface over time and the generation of open pores and microcracks during oxidation. Therefore, the majority of corrosion information tends to be empirical and based on experimental observations.

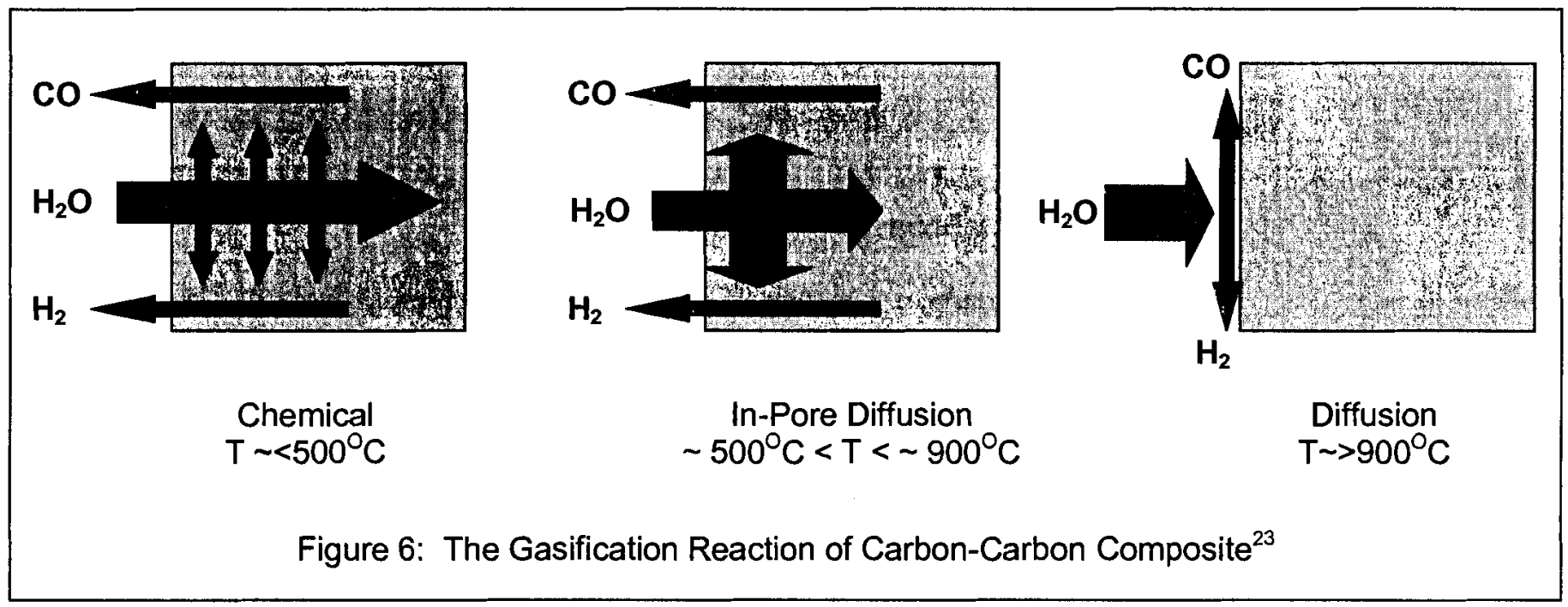

\subsection{Catalytic Corrosion and Role of Residual Impurities}

Residual impurities resulting from $\mathrm{C} / \mathrm{C}$ processing, for example CVD or impregnation, can also pose a concern in the operating environment (Table 5). Metallic impurities, specifically transition metals, have been shown to exhibit catalytic activity in the gasification of carbon materials. ${ }^{24}$ The gasification rates increase with increasing concentration of impurities. The effect is significant only if the amount of catalysts is sufficient. The small amount of impurities present may not play an important role in corrosion, but may allow transport of metallic impurities to refractory metals forming brittle intermetallics. The amount and types of impurities will differ for each $\mathrm{C} / \mathrm{C}$ vendor, and the role of residual impurities must be further investigated through experimental data. 


\begin{tabular}{|c|c|c|}
\hline \multicolumn{3}{|c|}{ Table 5: Impurities in $\mathrm{C} / \mathrm{C}$ material (ppm) } \\
\hline Impurity & Sample ${ }^{\mathrm{a}}$ & Sample $2^{6}$ \\
\hline Al & 3 & 2 \\
\hline $\mathrm{Ca}$ & 17 & 13 \\
\hline $\mathrm{Fe}$ & 11 & 4.1 \\
\hline $\mathrm{K}$ & 33 & N.D. \\
\hline Mg & 2.4 & 2.1 \\
\hline $\mathrm{Na}$ & 11 & 3.5 \\
\hline $\mathrm{Ni}$ & 0.8 & 0.6 \\
\hline $\mathbf{s}$ & 9 & 9 \\
\hline $\mathrm{Si}$ & 14 & 28 \\
\hline $\mathrm{Ti}$ & 0.8 & 3.6 \\
\hline V & 0.2 & 3.2 \\
\hline
\end{tabular}

\subsection{Compatibility with Fission Products}

Another factor to be taken into account is the impact of fission product release due to failed fuel elements. Fission products released from the fuel would be free to circulate throughout the system and deposit on the inner surfaces of system components. Some of the fission products of concern include $\mathrm{Ag}, \mathrm{As}, \mathrm{Cs}, \mathrm{I}, \mathrm{Pd}, \mathrm{Rb}, \mathrm{Ru}, \mathrm{Tc}, \mathrm{Te}$ and rare earths. ${ }^{15}$ These products are suspected of playing an important role in catalytic corrosion of $\mathrm{C} / \mathrm{C}$ material. Further testing is needed to understand the role of fission products on $\mathrm{C} / \mathrm{C}$ composite performance.

\subsection{Mitigating Corrosion Problems with Coatings}

A solution to mitigate carbon corrosion is to isolate the material from the high-temperature gas by coating the composite with a refractory system. The coating must possess low permeability to corrosive species, chemical compatibility with the substrate, good adhesion without excessive penetration, and comparable CTE to avoid spallation. ${ }^{26}$ Also, in order to maintain recuperator efficiency, the coating system must provide good thermal conductivity.

Coatings such as silicon carbide have been used extensively in the aerospace industry as a primary barrier to corrosion. SiC forms a protective $\mathrm{SiO}_{2}$ scale in pure oxygen, but problems arise in complex gas mixtures. When the oxygen potential is not sufficient, the protective $\mathrm{SiO}_{2}$ layer cannot form and weight loss occurs by decomposition or active oxidation. ${ }^{27} \mathrm{SiC}$ and $\mathrm{SiO}_{2}$ may chemically react with $\mathrm{H}_{2} \mathrm{O}$ and $\mathrm{H}_{2}$ in a low oxygen potential environment according to the following reactions: ${ }^{27,28}$ 


$$
\begin{gathered}
\mathrm{SiC}_{(\mathrm{s})}+2 \mathrm{H}_{2} \mathrm{O}_{(\mathrm{g})} \rightarrow \mathrm{SiO}_{(\mathrm{g})}+\mathrm{CO}_{(\mathrm{g})}+2 \mathrm{H}_{2(\mathrm{~g})} \\
\mathrm{SiC}_{(\mathrm{s})}+2 \mathrm{H}_{2(\mathrm{~g})} \rightarrow \mathrm{Si}+\mathrm{CH}_{4(\mathrm{~g})} \\
2 \mathrm{SiO}_{2}+3 \mathrm{H}_{2} \mathrm{O} \rightarrow \mathrm{SiO}(\mathrm{OH})_{2}+\mathrm{Si}(\mathrm{OH})_{4} \\
\mathrm{SiO}_{2(\mathrm{~s})}+\mathrm{H}_{2(\mathrm{~g})} \rightarrow \mathrm{SiO}_{(\mathrm{g})}+\mathrm{H}_{2} \mathrm{O}_{(\mathrm{g})}
\end{gathered}
$$

One of the principal limiting factors in the corrosion resistance of $\mathrm{SiC}$ coated $\mathrm{C} / \mathrm{C}$ composites is the formation of crack patterns in the $\mathrm{SiC}$ coating as a result of the thermal expansion mismatch between substrate and coating. ${ }^{27}$ Clearly, open cracks provide easy paths for ingress of corrosive species and serious localized damage to the carbon-carbon substrate. At the envisioned recuperator operating temperature, the viscosity of silica glass is too high to provide crack-sealing properties. Advanced coating systems may be more effective barriers to corrosion and constitute an important area for further evaluation and development.

Conclusions:

Carbon-carbon materials provide high-strength at low weight and can withstand temperatures forecasted for recuperator operation in a non-oxidizing environment. Also, $\mathrm{C} / \mathrm{C}$ composites present the opportunity to tailor their thermal or mechanical properties, which can be controlled by the different fiber, matrix, or processing options. Although this option exists, the method of production often becomes the cost-limiting factor in determining recuperator design.

$\mathrm{C} / \mathrm{C}$ composites present significant risks that can prohibit their adoption into the direct gas Brayton system. Foremost is the concern over compatibility issues. Incorporating a $\mathrm{C} / \mathrm{C}$ composite into the system would add yet another potential source of contaminants. The transport of carbon could lead to interstitial contamination of refractory metals and under some conditions carburization of superalloys. Also, the corrosion of $\mathrm{C} / \mathrm{C}$ composites reduces its strength and performance by the gasification of solid carbon. The corrosion reaction produces impurities that can drive the coolant chemistry into a regime where superalloys carburize, decarburize, or oxidize.

Integrating a carbon-carbon composite into an otherwise all-metallic energy conversion system raises concerns over joining. The CTE mismatch at $\mathrm{C} / \mathrm{C}$ to metal interfaces may create excessive thermal stresses causing failure at the joint and catastrophic gas leakage. The joining technology between $\mathrm{C} / \mathrm{C}$ and metal is underdeveloped and unproven for high-temperature joint reliability over a long mission lifetime.

Finally, the use of carbon-carbon as a recuperator material presents several fabrication issues. Due to reduced cost and ease of fabrication, a plain plate-fin design has been considered instead of a more efficient strip-fin design. Because of the lower heat transfer characteristics of plate-fin designs, $C / C$ recuperators are expected to carry an increase in volume compared to their metallic counterparts. Development of $\mathrm{C} / \mathrm{C}$ recuperators must also overcome obstacles such as fabricating uniform fin heights and properly joining plates to fins. 
Future Actions: In order to resolve the issues facing a $\mathrm{C} / \mathrm{C}$ recuperator core, experimental testing must be performed. Table 6 shows the tests needed to qualify $\mathrm{C} / \mathrm{C}$ composites for consideration in the Prometheus system. Of primary importance is the compatibility issue. Tests must be set up to determine the extent of materials degradation and to understand the underlying degradation mechanisms. Testing in helium with varying impurity levels over a range of temperatures representative of those experienced throughout the reactor plant will simulate anticipated thermal and environmental exposure.

\begin{tabular}{|c|c|c|c|}
\hline \multicolumn{4}{|c|}{ Table 6: Future Testing } \\
\hline Test & Purpose & Variables & Comments \\
\hline $\begin{array}{l}\text { Two-Retort } \\
\text { (once through) }\end{array}$ & $\begin{array}{l}\text { Compatibility } \\
\text { Screening-test } \\
\text { (mass transport) }\end{array}$ & $\begin{array}{l}\text { - Source }(C / C) \text { vs. sink material } \\
\text { (refractory metal/superalloy) } \\
\text { - Temp, time, gas chemistry }\end{array}$ & $\begin{array}{l}\text { - Fast }(100 \mathrm{hr} .) \text { and inexpensive } \\
\text { - Forced helium flow } \\
\text { - Determine preliminary mass transport } \\
\text { characteristics } \\
\text { - Measure input/output gas chemistry }\end{array}$ \\
\hline Helium Loop & $\begin{array}{l}\text { Compatibility } \\
\text { (thermodynamic } \\
\text { data) }\end{array}$ & $\begin{array}{l}\text { - Source vs. sink material } \\
\text { - Temp, time, gas chemistry, } \\
\text { pressure }\end{array}$ & $\begin{array}{l}\text { - Long-term }(1,000+\text { hr.) \& expensive equip. } \\
\text { - Natural helium convection with hot and cold } \\
\text { portions to insert samples. } \\
\text { - Determine thermodynamic data (reaction } \\
\text { rates, activation energies, etc..) for lifetime } \\
\text { prediction model }\end{array}$ \\
\hline \multirow[b]{2}{*}{$\begin{array}{l}\text { Fission } \\
\text { Product }\end{array}$} & $\begin{array}{l}\text { Compatibility } \\
\text { (capsule) }\end{array}$ & $\begin{array}{l}\text { - Fission product chemistry } \\
\text { - Temp, time, capsule material, } \\
\text { pressure, gas chemistry }\end{array}$ & $\begin{array}{l}\text { - Inexpensive and efficient } \\
\text { - Isothermal } \\
\text { - Determine fission product effect on } \\
\text { corrosion, mass-transport, etc.. }\end{array}$ \\
\hline & $\begin{array}{l}\text { Compatibility } \\
\text { (helium loop) }\end{array}$ & $\begin{array}{l}\text { - Fission product chemistry } \\
\text { - Temp, time, pressure, gas } \\
\text { chemistry }\end{array}$ & $\begin{array}{l}\text { - Long-term and expensive equipment } \\
\text { - Natural helium convection with hot and cold } \\
\text { portions to insert samples. } \\
\text { - Determine fission product effect on mass- } \\
\text { transport between source and sink material } \\
\text { - Determine thermodynamic data of fission } \\
\text { product compounds }\end{array}$ \\
\hline $\begin{array}{l}\text { Mechanical/ } \\
\text { Thermal/ } \\
\text { Other }\end{array}$ & $\begin{array}{l}\text { Build database } \\
\text { for specific } \mathrm{C} / \mathrm{C} \\
\text { material }\end{array}$ & $\begin{array}{l}\text { - Type of } \mathrm{C} / \mathrm{C} \text { material } \\
\text { - Type of testing } \\
\text { - Temp, environment }\end{array}$ & $\begin{array}{l}\text { - Tensile, flexural, shear strength } \\
\text { - Fracture toughness } \\
\text { - Creep, fatigue, creep-fatigue } \\
\text { - Thermal conductivity, CTE } \\
\text { - Permeability / metallic liner compatibility }\end{array}$ \\
\hline Joining & $\begin{array}{l}\text { Dissimilar } \\
\text { material joint } \\
\text { reliability }\end{array}$ & $\begin{array}{l}\text { - Type of } \mathrm{C} / \mathrm{C} \\
\text { - Refractory metal/superalloy } \\
\text { - Bonding technique } \\
\text { - Temp, time, gas chemistry, } \\
\text { pressure }\end{array}$ & $\begin{array}{l}\text { - Tensile, bend-ductility } \\
\text { - Non-destructive examination of joint } \\
\text { - Creep, creep-fatigue } \\
\text { - Creep/stress rupture } \\
\text { - Hermeticity }\end{array}$ \\
\hline
\end{tabular}

\section{Preliminary Screening Testing: Two-retort Test}

In order to determine preliminary mass transport properties of the $\mathrm{C} / \mathrm{C}$ material quickly and inexpensively, the two-retort test was established. ${ }^{29}$ The two retort test allows representative $\mathrm{C} / \mathrm{C}$ composite materials to be incorporated as a "source" of contaminants in the gas stream. Similar to current tests with superalloys and refractory metals, ${ }^{29}$ the $\mathrm{C} / \mathrm{C}$ material would be fabricated into thin plates and loaded into the front retort. The dimensions of the $\mathrm{C} / \mathrm{C}$ plates 
should reflect the ratio of recuperator surface area to the surface area of all "sink" material as estimated for the Prometheus system.

Ultra-high purity helium would flow past the $\mathrm{C} / \mathrm{C}$ material in the front retort at 950K and transport any released impurities into a second retort holding a sink material (e.g. refractory metal or superalloy). The second retort will be heated to the predicted operating temperature of the sink material. For instance, refractory metals used in the core would be heated to $1400 \mathrm{~K}$, whereas superalloys would reflect a turbine temperature of $1150 \mathrm{~K}$. The setup would also allow variation in impurity levels from test to test by using helium containers with different gas chemistries.

Tests would run for circa 100 hours with the oxygen level measured at both the inlet and outlet of the system. After each test, the sink and source material would be weighed to determine the amount of impurity uptake (sink) or release (source). Analysis such as optical microscopy or chemical analysis could also help determine the impact of mass transport. A dramatic change in weight (mass transport) would disqualify the $\mathrm{C} / \mathrm{C}$ material for further testing.

\section{Helium Loop Testing}

If the $\mathrm{C} / \mathrm{C}$ composite material shows to be sufficiently stable during preliminary screening, it would be incorporated into a long-term helium loop test. ${ }^{30}$ This test would help determine important thermodynamic data of the $\mathrm{C} / \mathrm{C}$ material by quantifying reaction rates and extent/rates of release and uptake of potential contaminants. The test would experimentally determine as a function of temperature and impurity concentration: ${ }^{15}$

- Activation energies and rates for impurity release and uptake

- Equilibrium levels of impurities/interstitials

- Effectiveness of control schemes

This data would then be incorporated into the Burden Model ${ }^{31}$ to help determine lifetime predictions.

\section{Fission Product Compatibility}

Provided the $\mathrm{C} / \mathrm{C}$ material passes preliminary tests, the compatibility with fission products would need to be assessed. Capsule testing under isothermal conditions is a fast and inexpensive way to determine this data. Representative $\mathrm{C} / \mathrm{C}$ material would be enclosed in a refractory or superalloy capsule with (nonradioactive isotope) fission product elements or mixtures of elements and heated to recuperator operating temperatures. The effect of the fission product on mass transport, corrosion, or mechanical properties would then be determined.

A more detailed approach to fission product compatibility is to incorporate the materials in the long-term helium loop. Potential fission products would be free to circulate in the primary system and deposit on surfaces of the components. The fission products are suspected of playing an important role on accelerated corrosion and deterioration of $\mathrm{C} / \mathrm{C}$ composite. This experiment would help understand fission product volatility, compound free energy, and the critical temperature at which the dominant species would affect the $\mathrm{C} / \mathrm{C}$ materials. 
Other Testing: Mechanical/Thermal Property and Permeability

Because carbon-carbon materials have wide variations in their mechanical and thermal properties, further testing would be necessary to qualify the $\mathrm{C} / \mathrm{C}$ composite chosen for recuperator core design. Experimental data is needed for the following properties:

- Tensile strength

- Flexural strength

- Shear strength

- Fracture toughness

- Creep

- Fatigue and Creep-fatigue

- Coefficient of Thermal Expansion

- Thermal conductivity

Testing is also needed to determine the composite permeability, and/or the compatibility between $\mathrm{C} / \mathrm{C}$ composite and potential metallic liners.

Joining

Due to the likelihood of a $\mathrm{C} / \mathrm{C}$ to metallic joint, joint reliability at hightemperatures must be studied. The first tier studies would function as a screening phase and would include tensile testing, bend-ductility testing, and non-destructive testing of the joint. Second tier studies would reflect long-term thermal effects under prototypical conditions. Testing would include: fracture toughness, creep, creep-fatigue, creep/stress rupture, and hermeticity.

AcknowledgeMents:

Prepared by:

Approved by:
Special thanks to Cheryl Bowman (NASA GRC) and the personnel at NASA GRC (Mrityunjay Singh - carbon-carbon composites, Evan Copeland thermodynamic model, and Mike Barrett - recuperator design) with their knowledge and experience. Thanks to J. Edington (Bettis), C.D. McCann (Bettis), and W.L. Ohlinger (Bettis) for their help in peer review.

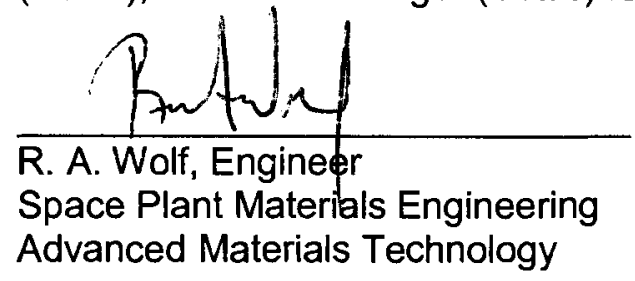


(This Page Intentionally Blank) 


\section{References}

${ }^{1}$ Barrett, M. J. "Performance Expectations of Closed-Brayton-Cycle Heat Exchangers in 100-kWe Nuclear Space Power Systems." NASA Glenn Research Center. NASATM - 2003- 21259, 2003.

${ }^{2}$ KAPL Letter SPP-67210-0001/ Bettis Letter B-SE-0037, "NR Program Assessment of the Design Space for the Prometheus 1 Project," November 2004.

${ }^{3}$ Clementoni, E. "Possible Coolant Temperature Ranges." NRPCT Clad Summit. Bettis Atomic Power Laboratory, Pittsburgh, PA. August 2005.

${ }^{4}$ Barrett, M.J. and Johnson, P.K. "Carbon-Carbon Recuperators in Closed-Brayton-Cycle Space Power Systems," $\underline{2}^{\text {nd }}$ International Energy Conversion Engineering Conference. AIAA 2004-5652, August 2004.

${ }^{5}$ Savage, G. Carbon-Carbon Composites, $1^{\text {st }}$ ed. Chapman \& Hall, 1993.

${ }^{6}$ Stevenson, R.D. and Vrable D.L. "Development of an Intermediate Temperature Carbon-Carbon Heat Exchanger for Aircraft Applications." $44^{\text {th }}$ International SAMPE Symposium. 44 (1999), pp. 1888-1897.

${ }^{7}$ Kearns, K.M., Anderson, D.P., and Watts, R. "Brazing of Carbon-Carbon for an Aircraft Heat Exchanger." $44^{\text {th }}$ International SAMPE Symposium. 44 (1999), pp. 1898 - 1908.

${ }^{8}$ Shei, Wei. Personal Communication with Allcomp, Inc. NASA SBIR Contract Number NNC04C73C, October 2005.

${ }^{9}$ SPP-67210-0010 / B-SE(SPS)-001 "Space Nuclear Power Plant Pre-Conceptual Design Report; for Information" Section 9.2: Component Descriptions - Recuperator, January 27, 2006

${ }^{10}$ Diefendorf, R. "Continuous Carbon Fiber Reinforced Carbon Matrix Composites." In Composites, Engineered Materials Handbook Vol. 1, edited by Dostal, C.A. et al (1987). ASM International: Metals Park, OH. pp. 816818.

${ }^{11}$ Policelli, F.J., and Vicario, A. "Space and Missile Systems." In Composites, Engineered Materials Handbook Vol. 1, edited by Dostal, C.A. et al (1987). ASM International: Metals Park, OH. pp. 911-914.

${ }^{12}$ Norton, B. "Cost Drivers in Design and Manufacture of Composite Structures." In Composites, Engineered Materials Handbook Vol. 1, edited by Dostal, C.A. et al (1987). ASM International: Metals Park, OH. pp. 419427.

${ }^{13}$ Kennel, E.B., and Deutchman, A.H., "Joining Carbon Composite Fins to Metal Heat Pipes Using lon Beam Techniques," Proceedings of Intersociety Energy Conversion Engineering Conference, Vol. 2 (1992) pp. 323328.

${ }^{14}$ Materials Resources International. "WideGap Joining: Powder Preform Technology." [Online] Available October 2001: http://www.materialsresources.com/widegap/widegap.htm.

${ }^{15}$ KAPL Letter MDO-723-0019/ Bettis Letter B-MT(SMAT)-5, "Space Materials Plan for Technical Approval," Attachment E, April 2005.

${ }^{16}$ Natesan, K., Purohit, A., and Tam, W. "Materials Behavior in HTGR Environments." Argonne National Laboratory. NUREG /CR-6824 ANL 02/37, February 2003.

${ }^{17}$ Graham, L.W. "Corrosion of Metallic Materials in HTR-Helium Environments." Journal of Nuclear Materials. 171 (1990) pp. $76-83$.

${ }^{18}$ Quadakkers, W.J. and Schuster, H. "Corrosion of High Temperature Alloys in the Primary Circuit Helium of High Temperature Gas Cooled Reactors. - Part I: Theoretical Background." Werkstoffe und Korrosion. 36 (1985) pp. $141-150$. 
${ }^{19}$ Christ, H.J., Schwanke, D., Uihlein, Th., and Sockel, H.G. "Mechanisms of High-Temperature Corrosion in Helium Containing Small Amounts of Impurities. I. Theoretical and Experimental Characterization of the Gas Phase" Oxidation of Metals. 30 (1988) pp. $1-26$.

${ }^{20}$ Kimball, O.F. "Thermal Stability and Environmental Compatibility of Inconel 617," Oak Ridge National Laboratory, Oak Ridge, TN, pp. $65-72$.

${ }^{21}$ Kimball, O.F. and Plumblee, D.E. "Gas/Metal Interaction Studies in Simulated HTGR Helium." General Electric Company, Schenectady, NY. HTGR-85-064, June 1985.

${ }^{22}$ Buckman, R.W. "Alloying of Refractory Metals, ${ }^{n}$ ASM International, Metals Park, OH, 1988.

${ }^{23}$ Katscher, W. and Moormann, R. "Graphite Corrosion Under Severe HTR Accident Conditions." IAEA Specialists' Meeting on Graphite Component Structural Design, Tokai-mura, Japan. JAERI-M 86-192, September 1986, pp. $182-188$.

${ }^{24}$ Nomura, S., Imai, H, Fujii, K., Shindo, M. "Relation Between Gasification Rates and Gas Desorption Behavior with Metallic Impurities of Carbon and Graphite Materials for the HTTR." JAERI. Tokai-mura, Japan, pp. $159-$ 168.

${ }^{25}$ Bowman, C. "C/C Composite Chemical Analysis Batch Results from C-CAT and BF Goodrich." NASA Glenn Research Center. Personal Communication, October 2005.

${ }^{26}$ Pierre, G.R. "Basic Thermodynamic Considerations Related to Oxidation Protection of Structural Carbon/Carbon Composites." Research into Structural Carbons, Ohio State University, Columbus, $\mathrm{OH}, \mathrm{pp}$. $409-438$.

${ }^{27}$ Perez, F.J. and Ghoniem, N.M., "Chemical Compatibility of SiC Composite Structures with Fusion Reactor Helium Coolant at High Temperatures." Fusion Engineering and Design. 22 (1993) pp. 415 - 426.

${ }^{28}$ Jacobson, N.S., Fox, D.S., and Opila, E.J., "High Temperature Oxidation of Ceramic Matrix Composites." Pure \& Applied Chemistry. 70 (1998) pp. $493-500$.

${ }^{29}$ Bettis Letter B-MT(SPME)-26, “Double Retort System for Materials Compatibility Testing," February 2006.

${ }^{30}$ Bettis Letter B-MT(SPME)-28, “Flowing Gas Test Loops for Material Compatibility Evaluation," February 2006.

${ }^{31}$ KAPL Letter MDO-723-0053, "Mass Transport Modeling for the Prometheus Space Nuclear Power Plant (SNPP)," January 2006. 